\title{
DIVADELNÉ UMENIE AKO NÁSTROJ INTEGRÁCIE PRE OSOBY SO ZDRAVOTNÝM ZNEVÝHODNENÍM: PRÍNOS DIVADLA PRE OSOBY S PORUCHOU AUTISTICKÉHO SPEKTRA
}

PETER MAZALÁN

Fakulta architektúry a dizajnu Slovenskej technickej univerzity

\begin{abstract}
Abstrakt: Štúdia analyzuje divadelné umenie v súvislosti s témou zdravotného znevýhodnenia, s akcentom na poruchy autistického spektra. Popri využití dramatického umenia v edukácii, sociálnej a klinickej praxi analyzujeme tento typ divadelného umenia v kontexte vybraných progresívnych európskych divadelných inštitúcií, ktoré pomáhajú zvyšovat' povedomie o neurodiverzite. Napriek tomu, že moderná medicína prispela ku zmene spoločenskej paradigmy smerom k ludskej populácii s rôznymi druhmi zdravotného znevýhodnenia, v súčasnosti je akceptácia a inklúzia zdravotne znevýhodnených l’udí stále sprevádzaná vysokou mierou ich stigmatizácie. Štúdia skúma formy inklúzie v divadle alebo prostriedkami divadla, ktoré vytvárajú kultúrnu a spoločenskú diverzitu, ktorá je pokračovaním v definovaní otvorenej a tolerantnej spoločnosti. Keď̌̌e diagnóza poruchy autistického spektra je v mnohých prípadoch kombinovaná s inými zdravotnými znevýhodneniami alebo je, naopak, v jej miernom spektre takmer nerozpoznatelná, jej definovanie v divadelnej praxi môže byt problematické. Preto v časti štúdie, kde analyzujeme takýto druh divadelnej práce, využívame označenie zdravotné znevýhodnenie.
\end{abstract}

Klúčové slová: divadelné umenie, herectvo, inklúzia, zdravotné znevýhodnenie, autizmus

\section{Aplikovanie divadla na nedivadelné účely: divadlo ako nástroj terapie}

Ak budeme uvažovat’ o terapeutických účinkoch divadla z historickej perspektívy, podobne ako pri dejinách performatívneho umenia nahliadneme do prehistorického obdobia civilizácie. Priamymi predchodcami dramatoterapie sú ale v kontexte dejín až mladé formy psychoterapie. ${ }^{1}$ Divadelné umenie je vo svojej performativite živým a neopakovatelným umením realizovaným $\mathrm{v}$ interakcii herca a diváka. A práve tento vzt’ah bol dôvodom, prečo sa psychoterapeuti v priebehu vývoja ich praxe zamerali na túto metódu ako na terapeutickú pomôcku. Divadelné umenie im poskytlo nový priestor, v ktorom sa klient mohol presunút k svojmu vnútru pomocou vlastnej kreativity primárne cez emócie a následne intelekt. ${ }^{2}$

Milan Valenta, vedec pôsobiaci v oblasti špeciálnej pedagogiky, opisuje psychodrámu ako dramatickú improvizáciu zameranú na terapeutické účely, ked’ klient dramatizuje svoje zážitky, priania, postoje či fantáziu. ${ }^{3}$ Dramatoterapia má v porovnaní s inými divadelno-terapeutickými postupmi najširšie možnosti využitia. Naj-

${ }^{1}$ Takýmito formami, ktoré využívajú divadelné techniky a postupy, sú napríklad Gestalt terapia, kognitívno-behaviorálna terapia, analytická terapia. Pozri VALENTA, M. Dramatoterapia. Praha : Portál, 2000, s. 11 .

${ }^{2}$ Pozri DUBAČOVÁ, V. Terapia divadlom. Nitra : Univerzita Konštantína Filozofa, 2013, s. 14.

${ }^{3}$ VALENTA, M. Dramatoterapia, s. 12. 
častejšou a najväčšou skupinu klientov sú mentálne postihnutí jedinci a l’udia s poruchou autistického spektra. ${ }^{4}$ Terapeutickú činnost’ vykonávajú profesionáli, ktorými sú špeciálni pedagógovia, psychológovia alebo lekári.

Jednou z priekopníckych osobností vo využívaní drámy a pohybu v terapii bola terapeutka Marian Lindkvist. Metóda známa ako Sesame approach (Sesame prístup), ktorú vytvorila na pomoc l'ud’om s rôznymi kognitívnymi a duševnými stavmi, spočíva v použití dotykov, rozprávaní príbehu, improvizácii a neverbálnej komunikácii. Na základe vlastných skúseností a v spolupráci so zanietenými hercami a zdravotníkmi založila v roku 1971 Sesame Inštitute. Zodpovedal za školenie stoviek l’udí $\mathrm{v}$ odboroch, z ktorých boli títo profesionáli prijatí na prax do nemocníc, denných centier, komunitných zariadení, škôl, väzníc alebo domovov pre seniorov. Lindkvist bola mnoho rokov riaditel'kou Sesame Institute v Londýne a zároveň pedagogičkou na jeho kurzoch, z ktorých sa neskôr vyvinulo magisterské štúdium v odbore dramatická a pohybová terapia. ${ }^{5}$ Príbeh inštitútu sa začal, ked' Marian Lindkvist potrebovala hl'adat' spôsoby, ako pomôct' svojej dcére Helen, ktorej diagnostikovali autizmus. $\mathrm{V}$ tom čase sa o tomto stave vedelo len málo a Lindkvist bola presvedčená, že jej diet’a vyžaduje niečo iné než štandardné zaobchádzanie, ktoré dostávala. ${ }^{6}$ Ked' koncom šest'desiatych rokov prišlo v USA a Vel'kej Británii k vymedzeniu oblasti dramatoterapie od predchádzajúcej praxe psychodrámy, začali vznikat’ samostatné profesijné asociácie. Preto v európskom kontexte existuje najkonzistentnejší výskum práve v britských organizáciách. ${ }^{7}$

Pri diagnostikovaní autizmu sa používajú predovšetkým dva hlavné diagnostické klasifikačné systémy, ktoré podliehajú aktualizáciám. Prvým je Diagnostic and Statistical Manual of Mental Disorders (Diagnostický a štatistický manuál duševných porúch, DSM-5, 2013), ktorý prináša v charakteristických definíciách tri samostatné poruchy autistického spektra: Aspergerovu poruchu, detskú dezintegračnú poruchu a všeobecnú diagnózu pervazívnej vývinovej poruchy. Druhým systémom je Internatinoal Classification of Diseases Svetovej zdravotníckej organizácie (Medzinárodná klasifikácia chorôb, ICD-10, 2010), ktorý autizmus charakterizuje ako vývojovú poruchu, ktorá je definovaná prítomnostou abnormálneho alebo narušeného vývoja a charakteristickým typom abnormálneho fungovania vo všetkých troch oblastiach psychopatológie: vzájomnou sociálnou interakciou, komunikáciou a obmedzeným, stereotypným a opakujúcim sa správaním. Popri týchto špecifických vlastnostiach je častý aj rad d’alších nešpecifických problémov, ako sú fóbie, poruchy spánku a stravovania, záchvaty hnevu a (samoriadená) agresia. ${ }^{8}$

$\mathrm{S}$ poruchou autistického spektra súvisí koncept neurodiverzity, ktorý vznikol

${ }^{4}$ Ďalšími technikami sú psychodráma, sociodráma, psychogymnastika a teatroterapia. Pozri tamže, s. 17.

${ }^{5}$ Marian Lindkvist prizvala k spolupráci lektorov z troch samostatných disciplín: Peter Slade sa venoval detskej dráme, Audrey Wethered Labanovej pohybovej analýze (metóda interpretácie a dokumentácie l’udského pohybu) a Molly Tuby pracovala s Jungovu psychológiou. V súčasnosti sa odbor vyučuje na Royal Central School of Speech and Drama v Londýne.

${ }^{6}$ Pozri PEARSON, J. Marian „Billy“ Lindkvist obituary, 15. 3. 2017. [online]. [cit. 20. 11. 2020]. Dostupné na internete: https://www.theguardian.com/society/2017/mar/15/marian-billy-lindkvist-obituary.

${ }^{7}$ Britská asociácia dramatoterapeutov (The British Association of Dramatherapists) je jedna z najstarších odborných organizácií tohto druhu.

${ }^{8}$ ICD-11, ktorá nahradí verziu ICD-10, je najnovšia verzia, ktorá vznikla v máji 2019 a dostane sa do platnosti v januári 2022. 
v devätdesiatych rokoch $\mathrm{v}$ komunite vysokofunkčných autistov. Zavedenie tohto termínu sa pripisuje sociologičke Judy Singer v štúdii Why Can't You be Normal for Once in Your Life? (1999). V širšom význame definuje koncept neurodiverzity všetky formy atypického neurologického vývinu ako normálne l’udské odlišnosti, ktoré by mali byt' rešpektované a tolerované vzhl'adom na svoju závažnost' ako ostatné l'udské diferenciácie. Neurodiverzita je vo svojom najširšom aplikovaní filozofiou spoločenského prijatia a rovnakých príležitostí pre všetkých jednotlivcov, bez ohladu na ich neurologické charakteristiky. ${ }^{9}$ Duševné poruchy sú jednou z hlavných tém Svetovej zdravotníckej organizácie v európskom regióne, kde postihujú každý rok až 25\% obyvatel'stva. Európa preto čelí rôznym výzvam, ktoré ovplyvňujú ako well-being (duševnú pohodu) obyvatel'stva, tak aj starostlivost’ o l'udí s problémami duševného zdravia. $^{10}$

Dramatoterapia využíva tvorivé médiá drámy, pohybu, hlasu a vel’a d’alších postupov na vývoj bezpečnej a fungujúcej metódy terapie. Aj ked' je dramatoterapeutický prístup aplikovatel'ný v širokej skupine l'udí, je zvlášt' užitočný pre tých, pre ktorých môže byt' priamy, verbálny alebo kognitívny prístup t’ažký. L’udí v autistickom spektre charakterizovala vo svojej štúdii vývojová a experimentálna psychologička Uta Frith ako l'udí, ktorí majú doslovnú formu myslenia, to znamená konkrétne hranice v emočnej inteligencii, teórii mysle a použití metafory. ${ }^{11}$ Výsledkom je, že ich správanie sa dá považovat’ za nevhodné alebo nezrelé, aj kvôli zhoršenej schopnosti porozumiet’ tomu, čo si myslia a cítia iní l'udia. Deti a dospievajúci l’udia s poruchou autistického spektra sú preto vystavení riziku úzkosti a depresie, ked’ si v miernejšej forme autistického spektra lepšie uvedomujú svoje sociálne postihnutia a obmedzené životné príležitosti. ${ }^{12}$ Dramatoterapia je pre túto skupinu klientov obzvlášt vhodná, pretože rozvíja sociálne zručnosti a podporuje vyjadrenie pocitov štruktúrovanou prácou, ktorá pomáha znižovat úzkost'. Znevýhodnení jednotlivci žijú často osamoteným životom. Výzvou sa pre nich môže stat', ako začat’ komunikovat’ so svetom, ktorý ich obklopuje. Dramatoterapia im môže pomôct' pri nácviku niektorých aspektov života a pri skúmaní jeho emocionálneho obsahu. Prostredníctvom improvizácie a hrania rol (pracovný pohovor, pohreb, romantická situácia atd'.) klient sleduje rôzne spôsoby vlastných reakcií a premýšla o nich v situáciách zo skutočného života. ${ }^{13}$

Kanadsko-americký psychológ Ervin Goffman v známej knihe The Presentation of Self in Everyday Life opisuje prípad ludskej interakcie, „,ked' bez ohladu na konkrétny ciel', ktorý chce jednotlivec dosiahnut', a bez ohl'adu na jeho motívy bude v jeho záujme kontrolovat' správanie druhých, predovšetkým ich reakcie na neho samotné-

\footnotetext{
${ }^{9}$ Pozri JAARSMA, P. - WELIN, S. Autism as a Natural Human Variation: Reflections on the Claims of the Neurodiversity Movement, 11. 2. 2011. [online]. [cit. 1. 12. 2020]. Dostupné na internete: https://link.springer. com/article/10.1007/s10728-011-0169-9.

${ }^{10}$ Pozri [Bez autora]. The European Mental Health Action Plan 2013-2020. September 2013. [online]. [cit. 1. 12. 2020]. Dostupné na internete: http://www.euro.who.int/_data/assets/pdf_file/0020/280604/WHO-Europe-Mental-Health-Acion-Plan-2013-2020.pdf.

${ }^{11}$ Pozri FRITH, U. Autism: explaining the enigma. Oxford : Blackwell Publishing, 1989.

12 Pozri GODFREY, E. - HAYTHORNE, D. Benefits of dramatherapy for Autism Spectrum Disorder. In Dramatherapy. 2013, roč. 35, č. 1, s. 20 - 28, 15. 4. 2013. [online]. [cit. 20. 11. 2020]. Dostupné na internete: https://www.tandfonline.com/toc/rdrt20/35/1?nav=tocList.

${ }^{13}$ Hranie roly moci môže mat podpornú funkciu pri nadobúdaní odvahy. Klienti vedia použit tvorivú fantáziu ako mechanizmus zvládania kompenzácie pocitov izolácie alebo ako príjemný duševný únik zo skutočného sveta.
} 
ho“14. Motívy jednania a správania mentálne znevýhodnených ludí sú, samozrejme, nastavené iným spôsobom. Preto sa aj divadlo pracujúce s takýmito osobami stáva súčastou akéhosi vedeckého výskumu a nie je možné ho tvorit iba ako príspevok $\mathrm{k}$ módnemu prúdu v performatívnych umeleckých formách. S autenticitou v tejto téme je prepojený aj eticko-medicínsky prístup ku zranitelnosti. ${ }^{15} \mathrm{~V}$ tomto koncepte sa uvažuje o integrácii znevýhodnených skupín cez ich pozitívne a silné stránky, ktorých môžu byt typickými nositelmi. Ak ide o druh „kognitívnej zranitel'nosti“, potom nie je etickou požiadavkou ju prekonávat', ale istým spôsobom ju stabilizovat’ a kontrolovat. ${ }^{16}$

\section{Divadlo autenticity}

Uvažovanie o zdravotnom znevýhodnení podla štúdie performerky a aktivistky v oblasti znevýhodnených umelcov Petry Kuppers prebieha na niekol'kých úrovniach: (1) „zdravotné znevýhodnenie ako skúsenost" ", ked” sa hl'adajú spôsoby, ako upozorňovat’ na skúsenosti znevýhodnených l’udí, ktoré pramenia z ich telesnej alebo mentálnej odlišnosti; (2) „zdravotné znevýhodnenie na verejnosti“, ktoré skúma, ako sa konceptualizujú konkrétne prípady znevýhodnenia pre umeleckú prax; (3) „zdravotné znevýhodnenie ako naratív", kde sa uvažuje, akým spôsobom sa zdravotné znevýhodnenie transformuje na javiská a do dejín divadla; (4) „zdravotné znevýhodnenie ako predstavenie, výjav", kde sa analyzuje, akým spôsobom l'udia využívajú svoj stav a situáciu ako významný nástroj. ${ }^{17}$

Predmetom reality, ktorú sledujeme zdivadelnenú na scéne, nebýva iba znevýhodnenie. Pre súčasné divadlo je charakteristické hl'adanie nových foriem, ktoré nezobrazujú realitu iluzívnym spôsobom, a napriek tomu sa ňou zásadným spôsobom zaoberajú. Práve z dôvodu, že spoločenská realita sa stáva čoraz viac zdivadelnenou, divadlo hl'adá spôsoby, ako formulovat takúto realitu bez spektakulárnych divadelných nástrojov. ${ }^{18}$

Pravdepodobne neexistuje iná forma umenia, v ktorej by boli l’udia so zdravotným postihnutím tak slabo zastúpení, ako je divadelné umenie, nakolko práca v divadle je - na rozdiel od iných, individuálne realizovatelných umeleckých foriem - závislá od širokého kolektívu, početných interakcií a vysokej miery koncentrovania sa pred publikom. Zaujímavú otázku v kontexte našej štúdie kladie divadelný teoretik a dramaturg Imanuel Schipper. Zaujíma ho, či sa interpret bez postihnutia javí byt’ horším alebo lepším sprostredkovatel'om ideí, alebo či je takáto interpretácia viac alebo menej autentická. „Existuje argument, prečo by mal byt umelec so zdravotným postihnutím autentickejší? Ako sa stanovuje autenticita, ktorá vytvára pre diváka autentický po-

\footnotetext{
${ }^{14}$ GOFFMAN, E. Všichni hrajeme divadlo. Praha : Nakladatelství Studia Ypsilon, 1999, s. 12.

${ }^{15}$ Konceptom zranitel'nosti v medicínskej etike a filozofii sa zaoberá aj "medzinárodný etický kódex“, dokument s názvom Statement of Ethical Principles (IFSW, 2018), ktorý do slovenského jazyka môžeme preložit’ ako Vyhlásenie etických princípov (sociálnej práce), resp. Deklarácia etických princípov. [online]. [cit. 11. 2. 2021]. Dostupné na internete: https://socialniprace.cz/aktualne-trendy-noveho-medzinarodneho-etickeho-kodexu/.

${ }^{16}$ BOLDT, J. The Concept of Vulnerability in Medical Ethics and Philosophy. In Philos Ethics Humanit Med, 2019, roč. 14, č. 6. [online]. [cit. 11. 2. 2021]. Dostupné na internete: https://doi.org/10.1186/s13010-019-0075-6.

${ }^{17}$ KUPPERS, P. Divadlo a zdravotné znevýhodnenie. Bratislava : Divadelný ústav, 2019, s. 14.

${ }^{18}$ Pozri DREYSSE, M. - MALZACHER, F. Experten des Alltags. Das Theater von Rimini Protokoll. Berlin : Alexander Verlag, 2007, s. 10.
} 
cit?"19 Čiastočne na tieto otázky odpovedá aj vyššie spomenutá Goffmanova štúdia. Motivácia v našom kontexte mentálne znevýhodnených l'udí nepramení z vôle niečo dokazovat alebo urputne predstierat. Goffman hovorí o výklade situácie aj ako o „vnútornom tajomstve", ktoré oprávňuje stat’ sa pre účinkujúcich ale i recipientov súčastou akejsi skupiny „zasvätených“: „Vnútorné tajomstvá dodávajú objektívny intelektuálny obsah subjektívne prežívanému spoločenskému odstupu. “20 V prípade týchto l'udí znamená totiž ich vnútorný svet tajomstvo, a teda najvyššiu mieru ich autenticity.

Inou analýzou autenticity pri interpretácii hercov so znevýhodnením môže byt ostenzia v divadelnom umení, ktorú definoval semiotik a divadelný a literárny teoretik Ivo Osolsobě. Teatrologička Elena Knopová vo svojej štúdii Na ceste od terapie ku komunitnému umeniu popisuje takýchto hercov ako „schopných tvorit nie iba divadelnú ilúziu či performatívnu sebavýpoved”, ale tiež "disponujúcich v každom momente prítomnou bytostnou úprimnostou“. ${ }^{21}$ Takýto interpret je zásadným spôsobom schopný eliminovat’ akúkol'vek potrebu práce s dodatočným scénickým elementom. Významným nositel'om znakov a javiskovým prvkom, ktorý býva v konceptoch nami skúmaného divadla často potláčaný, je aj štylizovaný kostým, ktorý „,sa dostáva do konfrontácie s otázkami zmeny identity, modifikácie či maskovania“22.

Spôsob, akým vzniká divadlo, vždy referuje k spoločnosti, pre ktorú sa divadlo tvorí. Túžba po väčšej integrácii ludí so zdravotným postihnutím na javiskách predstavuje teda túžbu po ich väčšej integrácii v spoločnosti. Pozornost’ by mala byt rovnomerne venovaná aj neviditelným postihnutiam, aby si l'udia uvedomili predsudky voči všetkým osobám so zdravotným znevýhodnením, a teda aj problémy, ktorým čelia tí, ktorí nezodpovedajú obvyklým stereotypom. Vnímanie hereckého tela sa mení v histórii a v preferenciách jednotlivých tvorivých prístupov. Ako konštatuje britská divadelná historička Colette Conroy v publikácii Theatre and The Body (2009), „,telo je pre Sarah Bernhardt nástrojom, ktorý treba prekonat' kvalifikovaným inštrumentom. Podl'a Stanislavského je telo limitujúcim faktorom a podla Becketta je metafora obmedzujúcich skúseností l’udskej psychiky i neschopnosti uniknút zo svojich bolestivých obmedzení. “23

O divadle znevýhodnených môžeme uvažovat' už koncom 19. storočia, ked' sa do ústavov pre choromysel'ných chodila na klientov za vstupné dívat široká verejnost'. Jednou z takýchto liečební bol aj Earlsfield Asylum for Idiots v Earlsfielde v Anglicku, kde pôsobil doktor John Langdon Haydon Down (podla neho je pomenovaný Downov syndróm). V ústave postavil javisko, kde organizoval predstavenia svojich klientov, ktorí „majú značnú silu predstavivosti, ktorá dokonca hraničí s tým, že vedia dobre napodobňovat' iných. Sú vtipní a živý zmysel pre komickost’ často podfarbuje ich imitačné schopnosti. ${ }^{24}$

${ }^{19}$ SCHIPPER, I. Einleitung. In Ästhetik versus Authentizität? Reflexionen über die Darstellung von und mit Behinderung (Ed. I, Schipper). Berlin : Theater der Zeit, 2012, s. 9. Preklady z cudzích jazykov P. M.

${ }^{20}$ GOFFMAN, E. Všichni hrajeme divadlo, s. 141.

${ }^{21}$ KNOPOVÁ, E. Na ceste od terapie umením ku komunitnému divadlu. In Divadlo nielen ako umelecká aktivita. (BALLAY, M. et al.). [online]. [cit. 8. 2. 2021]. Bratislava : SAV, 2014, s. 38. Dostupné na internete: http://www.udfv.sav.sk/dokumenty/Divadlo.nielen.ako.umelecka.aktivita.pdf.

${ }^{22}$ NAGYOVÁ, N. K základným atribútom výtvarnej poetiky Petra Čaneckého so zameraním sa na inscenácie v réžii Romana Poláka. In Slovenské divadlo, 2020, roč. 68, č. 1, s. 47. DOI: https://doi.org/10.31577/ sd-2020-0004.

${ }^{23}$ Cit. podla slovenského prekladu CONROY, C. Divadlo a telesnost'. Bratislava : Divadelný ústav, 2017, s. 100.

${ }^{24}$ KUPPERS, P. Divadlo a zdravotné znevýhodnenie, s. 69. 
V tomto období sa bežne konali v prednáškových aulách prezentácie mentálne znevýhodnených l’udí. Pacienti dávali k dispozícii svoje telo, ktoré nemali pod kontrolou. Takéto prednášky mali vel’a spoločného s freak show (bizarnými predstaveniami). V 19. a 20. storočí sa v cirkusoch a na vel'trhoch predstavovali takzvaní čudáci: obri a nízke postavy, chlpatí l’udia, siamské dvojčatá a mnoho d’alších. Slúžili na voyeuristické potreby prezerania a zároveň plnili sebaistotu v zmysle „špecifickej normality v kultúre pozorovatel'a“25. Verejné vnímanie čudákov a zmrzačených l’udí verejnostou sa aj vplyvom prvej svetovej vojny zmenilo z posmechu na súcit. ${ }^{26}$ Freak show postupne zmizli zo scény, ked’že stratili svoje opodstatnenie. Niektoré zdroje uvádzajú ako dôvod straty záujmu o túto formu prezentácie nástup média filmu. ${ }^{27}$ Nastal koniec podivuhodných predstavení a kabinetov kuriozít. Teoretička divadla Yvonne Schmidt však vo svojej štúdii o freak show píše, že zvláštna forma predvádzania sa nad’alej odohráva v nových formátoch. V divadelnej praxi s postihnutými hercami podla nej žáner freak show pokračuje odlišným spôsobom a bizarné predstavenie sa posunulo do svojich d’alších etáp. ${ }^{28}$

\section{Diváci}

Približne v roku 2009 sa v anglickom a americkom divadelnom prostredí rozvinuli tzv. relaxed performances. Predstavenia sú organizované pre doposial' zanedbávaných alebo menšinových divákov, ktorým je z objektívnych dôvodov tažké dodržiavat’ obvyklé konvencie divadelného správania. ${ }^{29}$ Pôvodne vznikali predovšetkým pre ludí s poruchou autistického spektra. ${ }^{30}$ Rozdiel oproti štandardným produkciám je predovšetkým v práci so svetelnou a zvukovou škálou javiskových prostriedkov, a to v ich zníženej intenzite. Predstavenia tiež poskytujú špeciálne zaškolený personál, ktorý je k dispozícii, aby divákov oboznámil s dielom. ${ }^{31} \mathrm{~V}$ Európe ponúka vo väčších inštitúciách takýto druh predstavení predovšetkým Anglicko. To má podl’a zákona o rovnoprávnosti z roku 2010 zákonnú povinnost’ prijat’ všetky primerané kroky na sprístupnenie svojich služieb pre l’udí so zdravotným postihnutím. ${ }^{32}$ Výnimkou nie je ani National Theatre v Londýne, ktoré na svojej webovej stránke uvádza súbor detailných informácií k takýmto podujatiam. ${ }^{33}$ Divadlá ponúkajúce špecifickú dramaturgiu

${ }^{25}$ DEDERICH, M. Körper, Kultur und Behinderung. Eine Einführund in die Disability Studies. Bielefeld : Transcipt, 2007, s. 101.

${ }^{26}$ Pozri GOTTWALD, C. Lachen über das andere. Eine historische Analyse komischer Repräsentationen von Behinderung. Bielefeld : Transcript, 2009.

${ }^{27}$ Pozri SCHEUGL, H. Show - Freaks und Monster. Sammlung Felix Adanos. Köln : DuMont Schauberg, 1978.

${ }^{28}$ Pozri SCHMIDT, Y. Perform to be a Freak. In Ästhetik versus Authentizität? Reflexionen über die Darstellung von und mit Behinderung, s. 119.

${ }^{29}$ L’udia s poruchami učenia, pohybovými poruchami, poruchou autistického spektra, inými neurologickými stavmi, tourettovým syndrómom alebo osoby s malými det’mi. Pozri [Bez autora]. Relaxed Performances, 16. 3. 2016. [online]. [cit. 25. 8. 2020]. Dostupné na internete: https://www.touretteshero.com/2016/03/16/ relaxed-performances-the-faqs/.

${ }^{30}$ Autism - friendly, sensory - firendly performances. Pozri [Bez autora]. Relaxed Performance. [online]. [cit. 15. 10. 2020]. Dostupné na internete: https://diversity-arts-culture.berlin/en/node/127.

${ }^{31}$ Pozri FLETCHER - WATSON, B. Relaxed performance: audiences with autism in mainstream theatre. In The Scottish Journal of Performance. 2015, roč. 2, č. 2 s. $61-89$.

32 Pozri [Bez autora]. Equality Acts 2010. [online]. [cit. 15. 10. 2020]. Dostupné na internete: https://www. legislation.gov.uk/ukpga/2010/15/contents.

${ }^{33} \mathrm{~V}$ Nemecku alebo Francúzsku sú to predovšetkým divadelné festivaly a príležitostné inscenácie, ktoré 
sú si vedomé skutočnosti, že aj architektonické prostredie je organickou súčastou ich konceptu a dôležitým aspektom úspešného aplikovania univerzálneho prístupu k človeku v kontexte dostupnosti. V teórii architektúry sa píše o priestore interiéru ako o mieste, v ktorom trávime najviac času. Architekt Michal Hronský charakterizuje interiéry ako miesto, ktoré „vyvoláva a určuje emocionálno-estetickú reakciu človeka. Medzi objektívne faktory vnímania zarad’ujeme tie antropologické a psycho-fyziologické faktory, ktoré sú charakteristické pre všetkých l’udí.“34

Teoretik literatúry a umenia so zameraním na znevýhodnené skupiny l’udí Tobin Siebers vo svojej štúdii interpretuje Aristotelesovu Poetiku spôsobom, že „potešenie v dráme nepochádza z formálnych aspektov imitácie, jej prevedenia, ale od chvíle, ked' si divák uvedomí podobnost̉ imitácie s predchádzajúcou životnou skúsenostoo$\mathrm{u}^{\prime \prime 35}$. Divákovo potešenie teda vychádza z príbuznosti interpretovaného javu a jeho situácií z reálneho života. Siebers d’alej analyzuje Aristotela tvrdením, že „naše potešenie z napodobňovania nemá vel’a spoločného s naším potešením alebo bolestou z napodobneného. Pozeráme sa na obrazy vecí, na ktoré sa my sami zdráhame pozerat', a s potešením, najmä ak sú vyrobené so zvláštnou precíznostou, ako sú postavy najohavnejších tvorov a mŕtvych tiel. ${ }^{\text {} 36}$

Sigmund Freud ponúka teóriu v súvislosti s postihnutím v diele Psychopathische Personen auf der Bühne (1942), kde tvrdí, podobne ako Aristoteles, že utrpenie, zranenie a neštastie robia divadlo „príjemným“ ${ }^{37}$ Freud charakterizuje drámu vztahom k utrpeniu a neštastiu: všetky druhy utrpenia sú témou drámy, od ktorej si sl'ubuje potešenie pre recipienta. V divadle podl'a Freudovej tézy sa diváci ale odmietajú identifikovat’ s postihnutými postavami. Divadlo ako živé a procesuálne umenie, kde je recepcia a produkcia v jednej horizontálnej časovej rovine, dokáže v juxtapozícii s inými médiami ovládat’ stelesnené zobrazenie pocitov, tzv. embodied mind (vtelená kognitívnost'). Vcítenie sa tu nezameriava na reprezentáciu, ale na prítomnost'. Imaginácia diváka $v$ tomto prípade neznamená nič iné ako predstavu alebo vcítenie sa do dlhotrvajúceho diskomfortu na vlastnom tele - stelesnené zobrazenie pocitov. ${ }^{38}$ Ak by sa publikum s nekomfortným, v našom prípade postihnutým telom identifikovalo, stratí podl'a Freuda zo sledovania pôžitok. Také telo by podl'a neho malo byt’ len „rekvizitou“39, zatial” čo sledovanie a skúmanie duševných problémov, s ktorými hrdina zápasí, v divákovi generuje skôr súcit a priazeň.

Zdravotné postihnutie reprodukované na javisku ponúka formu identifikácie. Je to identita, ktorá sa divácky neprijíma ani neodmieta, ale sa transformuje. V tomto

ponúkajú takto spracované produkcie (z väčších festivalov napríklad NO LIMITS festival v Berlíne alebo platforma integrART vo Švajčiarsku).

${ }^{34}$ HRONSKÝ, M. Vnímanie vnútorného priestoru, kompozičné princípy. In Interiérový dizajn (DANIEL, P. et al.). Bratislava : Spektrum, 2017, s. 18.

${ }^{35}$ SIEBERS, T. Un/Sichtbar. Observationen über Behinderung auf der Bühne. In Ästhetik versus Authentizität? Reflexionen über die Darstellung von und mit Behinderung, s. 23.

${ }^{36}$ Tamže, s. 23.

${ }^{37}$ FREUD, S. Psychopatische Personen auf der Bühne. In MITSCHERLICH, A. et al. Freud - Studienausgabe . Frankfurt am Main : Fischer, 1969, s. 164.

${ }^{38}$ Porov. TIGGES, S. - PEWNY, K. - DEUTSCH-SCHREINER, E. et al. Zwischenspiele - Neue Texte, Wahrnehmungs und Fiktionsräume in Theater, Tanz und Performance. Bielefeld : Transcript Verlag, 2010, s. 325. Pozri napr. hru Die Ratten od Olafa Altmanna v réžii Michaela Thalheimersa.

${ }^{39}$ FREUD, S. Psychopatische Personen auf der Bühne. In MITSCHERLICH, A. et al. Freud - Studienausgabe, s. 165. 
okamihu emocionálneho uvedomenia seba samého môže divák pochopit,, že aj krehkost' vítazí nad silou, choroba predčí zdravie a stratu komplexnosti.

\section{$\mathrm{Ne} / \mathrm{herec}$}

Teoretici v štúdiách o zdravotnom postihnutí tvrdia, že telesné postihnutie v majoritnej spoločnosti je samé o sebe výrazným nositel’om performatívnych prvkov. ${ }^{40}$ Zdravotne postihnutý človek tak býva aj vo svojom reálnom živote vystavený na pomyselnej scéne. „Ked' postihnuté telo vstúpi do miestnosti, všetci na neho dôsledne pozerajú, akoby sa presunulo do stredu javiska. Miestnost’ napĺñajú živé emócie," tvrdí Siebers. ${ }^{41}$

Práca s neprofesionálnymi hercami stojí za koncepciou mnohých projektov, ktoré sledujú estetické, nie sociálno-výchovné ciele. Je vidiet hercov, ktorí zjavne nemajú vokálny ani fyzický divadelný tréning, neovládajú dokonale svoje telo a tažko dokážu interpretovat’ - hrat' úlohy. Napriek tomu sa verejnost' zdráha hovorit’ o amatérskej hre. Tá býva spájaná s vysoko zanietenými hercami, ktorí sa prejavujú s vel'kým nasadením, ale malou remeselnou zručnostou. Nevzdelané a amatérske telá na javisku kreovali a provokovali dôležité fázy v historickom vývoji divadla. Až v 20. storočí dostal herec pravidelné akademické vzdelanie na univerzite, ktoré musel preukazovat' štátnymi skúškami. Podl’a teoretika divadla Jensa Roselta táto historická a štrukturálna dimenzia naznačuje, že vzt’ah profesionálneho a amatérskeho hereckého umenia je zložitejší, než sa na prvý pohl’ad zdá. ${ }^{42}$

Uplatnenie autistických hercov a ich akceptácia na javisku je stále považovaná za marginálnu. Petra Kuppers uvádza tento problém vo svojej štúdii na príklade produkcie hry Curious Incident na West End/Broadway..$^{43}$ Hra, v ktorej hlavný hrdina prejavuje známky poruchy autistického spektra, vzbudila v autistickej verejnosti otázky súvisiace s hereckým obsadením postavy neautistickým interpretom. Podla odbornej aj autistickej verejnosti sa tak premrhala príležitost' priniest' hre d’alší rozmer vo vztaahu k umelcom so zdravotným znevýhodnením. Hoci sa produkčný tím s režisérom snažili navonok komunikovat’ záujem o znevýhodnených interpretov, ich obsadenie sa nezrealizovalo. Dozaista, išlo o komerčný projekt, ktorý hrá na istotu, nie o alternatívne alebo edukatívne predstavenie, no vzbudil aktívnu diskusiu o vyjadrovacích prostriedkoch a možnostiach súčasného divadla.

Jedným z dôvodov, prečo niektoré produkcie nedôverujú spolupráci s osobami so zdravotným znevýhodnením, je obava z neporozumenia. Jazyk, ktorým sa dorozumievame predovšetkým v bežnej komunikácii, využíva vysokú mieru metaforického vyjadrenia, pričom si neuvedomujeme, že naša komunikácia je z významnej časti neexplicitná. Schopnost’ porozumenia metaforickému jazyku sa tak javí ako nevyhnutná k porozumeniu a ku komunikácii. Nedoslovný prenos informácie, umožňujúci porozumiet, je spolu s jazykom metafory úzko prepojený so psychoanalýzou

\footnotetext{
${ }^{40}$ Pozri SANDAHL, C. Ahhhh Frea Out! Metaphors of Disability and Femaleness in Performance. In Theatre topics, 1999, roč. 9, č. 1, s. 12.

${ }^{41}$ SIEBERS, T. Un/Sichtbar. Observationen über Behinderung auf der Bühne. In Ästhetik versus Authentizität? Reflexionen über die Darstellung von und mit Behinderung, s. 20.

${ }^{42}$ ROSELT, J. Der Zuschauer als Täter. Tamže, s. 85.

${ }^{43}$ KUPPERS, P. Divadlo a zdravotné znevýhodnenie, s. 24.
} 
a psychoterapiou. Metafora sa používa nielen ako most k nevedomej mysli, ale aj ako spôsob, akým teoretici a odborníci v oblasti komunikácie komunikujú o nevedomej mysli. Freud hovoril o tom, že „myslenie v obrazoch“ je „bližšie k nevedomým procesom než (...) myslenie slovami“, takže "premýšl’anie v obrazoch" alebo použitie metafory môže umožnit’ prístup k emocionálnemu materiálu a diskusiu o ňom. ${ }^{44}$

Jedinci s autizmom, ktorí mali sprievodné štrukturálne jazykové deficity, boli pri výskumnej úlohe s použitím metafory v jej riešení na nerozoznanie od detí s jazykovým postihnutím, ktoré nemali klinicky významné autistické znaky. Ďalšie porovnávacie štúdie a výskumy tiež dokazujú, že l'udia s poruchou autistického spektra sú schopní po vhodných edukatívnych intervenciách generovat’ a porozumiet’ metaforickému jazyku. ${ }^{45}$

\section{Divadelná prax ako nástroj integrácie.}

\section{RambaZamba Theater, Theater Thikwa, Theater HORA}

Skutočnost', že divadlo pre zdravotne postihnutých si v poslednej dobe získalo mediálny záujem, je výsledkom dobrej mediálnej propagácie smerom k širokému publiku, predovšetkým nemeckých festivalov a divadelných inštitúcií. Dopomáhajú tomu aj nové stratégie $\mathrm{v}$ rozvoji sociálnych programov pre znevýhodnených l'udí na rôznych úrovniach. K rozšíreniu publika a záujmu o takéto divadlo prispelo napríklad úspešné hostovanie zürišského súboru Theater HORA na prestížnom festivale Theatertreffen v Berlíne v roku 2013. V ich produkcii Disabeld Theatre (réžia Jérôme Bel) vtedy získala významné ocenenie Alfred-Kerr-Darstellerpreis zdravotne znevýhodnená herečka Julia Häusermann. Záujem vzbudili aj zásadné projekty v berlínskom Theater Thikwa. Ďalším známym zoskupením je Theater RambaZamba v Berlíne. Ich diela sú uvádzané na festivaloch ako No Limits alebo Grenzenlos. Prvé predstavenia každého z týchto divadiel začiatkom devät’desiatych rokov vyvolali a stále vyvolávajú enormnú odozvu verejnosti. V období svojho vzniku podporili diskusiu o umeleckých schopnostiach ludí s mentálnym postihnutím. Súbory boli vzájomne inšpirované a vyslali dôležitý signál o chápaní inklúzie v novej perspektíve, $\mathrm{v}$ kontexte moderného profesionálneho divadelného jazyka.

Spomenuté súbory sa nesnažia iba vágne začleňovat moderný pojem inklúzia do praxe. V programovom bulletine predstavenia Am liebsten zu dritt divadla RambaZamba jeho tvorcovia píšu, že toto často používané slovo, ktoré prekonáva realitu, predpokladá, že v existujúcej štruktúre je zahrnuté niečo cudzie. V týchto divadlách ale vytvárajú vlastné štruktúry podl'a svojich potrieb a možností znevýhodnení herci. Sú to práve oni, zdravotne postihnutí, ktorí sú schopní a ochotní otvorene nás, „normálnych l'udi'", objat' a prijat. ${ }^{46}$

Divadlo RambaZamba sídliace v berlínskom Kulturbrauerei funguje na princípe ansámblového mestského divadla s hercami bez aj so zdravotným znevýhodnením. Je miestom, kde hostuje mnoho významných berlínskych hereckých osobností, a rov-

\footnotetext{
${ }^{44}$ FREUD, S. The Ego and the Id. In TACD Journal, 1989, roč. 17, č. 1, s. 5 - 22.

${ }^{45}$ Pozri KASIRER, A. - MASHAL, N. Comprehension and generation of metaphors by children with autism spectrum disorder. In Research in Autism Spectrum Disorders, 2016, roč. 32, december, s. 53 - 63. [online]. [cit. 20. 9. 2020]. Dostupné na internete: https://psycnet.apa.org/record/2016-54476-006.

${ }^{46}$ LINZER, M. Inklusion - was'n ditte? In Theater der Zeit, 2014, roč. 68, č. 4, s. 16.
} 
nako si získalo priazeň a uznanie odbornej divadelnej obce. Divadlo v roku 1990 založili herečka a divadelná vedkyňa Gisela Höhne a režisér Deutsches Theater Berlin Klaus Erforth, ktorí sú zároveň rodičmi syna s Downovým syndrómom, ktorý bol prvým členom ansámblu. ${ }^{47}$ Gisela Höhne opísala prácu v ich divadle už v roku 1996 ako „odmietnutie racionálnych, akademických a protirečiacich si noriem a presadzovanie autentických umeleckých prejavov“"48. Prácu v súbore nepovažuje za terapeutickú činnost', ale predovšetkým za d’alší proces vzdelávania a nadobúdania skúseností. Ich repertoár vo väčšine netvoria tituly, kde sa špeciálne poukazuje na znevýhodnenia hercov. Silným dielom bol však projekt Mongopolis (2009) na motívy filmu Metropolis (1927) od Fritza Langa. Mongopolis reagoval na vtedy aktuálnu tému pre-implantačnej genetickej diagnostiky a prenatálnej diagnostiky. Ciel'om nebolo zapojit sa do ideologického sporu pro-live a pro-choice, ale „otázka znela, či by sme existovali vôbec my, blázni a tvorivé bytosti“49. Ich najtažšia inscenácia - vzhladom k téme, ktorá sa ich bytostne dotýka - je doposial' ich najhranejším titulom.

Divadelné zoskupenie Thikwa bolo, podobne ako divadlo RambaZamba, založené v roku 1990 s ciel'om propagovat' tvorbu zdravotne postihnutých a zdravých umelcov v rôznych umeleckých odvetviach. Hlavnými zakladatel’mi sú Hanna Näter, Gerlinde Altenmüller a Matthias Maedebach, v súčasnosti divadlo riadia Nicole Hummel a Gerd Hartmann. ${ }^{50}$ Súbor sa kreoval postupne z workshopových aktivít chránených dielní, ktoré vyústili do snahy o profesionalizáciu realizovaných performatívnych aktivít. V roku 1995 vznikol workshop Thikwa, ktorý sa odvtedy prevádzkuje v spolupráci s Nordberliner Werkgemeinschaft - dielňami pre l’udí so zdravotným postihnutím. V období rokov 1995 - 1997 išlo v Nemecku o pilotný projekt financovaný spolkovým ministerstvom zdravotníctva, ktorý testoval rehabilitáciu a vzdelávací model mentálne postihnutých l'udí novou formou umeleckých aktivít a ich režimu v systéme starostlivosti. Od roku 2010 sa organizácia oficiálne nazýva Thikwa Workshop for Theatre and Art Workshop. V súčasnosti má 44 zamestnancov so zdravotným postihnutím a je rozsiahlym kompetenčným centrom pre rôzne umenia. Títo zamestnanci tvoria súbor divadla Thikwa. Profesionalizácia prostredníctvom rozsiahlej ponuky školení a súvisiaceho výskumu špeciálnych estetických a obsahových možností inkluzívnej divadelnej práce priniesla súboru rešpekt na poli profesionálneho divadelníctva i v medzinárodnom kontexte. Termín inklúzie bol v devätdesiatych rokoch ešte nový, práca zoskupenia ho však preniesla do kontextu divadelnej praxe akceptovaním odlišnosti aj v profesionálnom divadle. Priestory súboru sú od roku 2008 situované v berlínskom Mühlenhaupthöfe, ide o prvé úplne bezbariérové divadlo v Nemecku. Thikwa každý rok uvedie 10 až 12 rôznych inscenácií v 70 až 90 predstaveniach.

Vznik súboru Theater HORA bol inšpirovaný hostujúcim predstavením divadla Thikwa v zürišskom Theaterhaus Gessnerallee. Založili ho režisér a divadelný pedagóg Michael Elber a sociálna pracovníčka Gerda Fochs v roku 1993. Združenie má

\footnotetext{
${ }^{47}$ Pozri [Bez autora]. Theater Rambazamba. [online]. [cit. 1. 11. 2020]. Dostupné na internete: https://web. archive.org/web/20070403132354/http://www.theater-rambazamba.org/Aboutus/selbstdarst.

${ }^{48}$ LINZER, M. Inklusion - was'n ditte?, s. 16.

${ }^{49}$ Tamže, s. 17.

${ }^{50}$ Pozri [Bez autora]. Theater Thikwa. [online]. [cit. 1. 11. 2020]. Dostupné na internete: https://www. thikwa.de/ueber-thikwa/ueber-thikwa-profil/.
} 
za ciel' ponúknut’ talentovaným mentálne postihnutým hercom profesionálne divadelné prostredie. HORA bol jedným z posledných základov priekopníckej generácie takzvaného integratívneho divadla, kde znevýhodnení ludia už nie sú zapájaní primárne z terapeutických alebo zdravotno-politických dôvodov, ale do popredia sa dostáva umelecká motivácia - ich práca je príspevkom k pravidelným kultúrnym ponukám. Názov HORA je prevzatý od postavy z prvej inscenácie divadla-Aber Zeit ist Leben. Und das Leben wohnt im Herzen (1993), adaptácie detského románu Michaela Mesta Momo. Majster Hora je ten, kto dáva l'ud'om čas. ${ }^{51}$ Umelecký šéf Michael Elber v prvých rokoch súboru neustále experimentoval s možnostami divadelnej práce s postihnutými hercami a skúšal nové formáty pre túto špeciálnu formu divadla, od performatívnej divadelnej inštalácie cez klasické tituly až po hudobné divadlo.

\section{Rimini Protokoll a Manifest NTGent ako dramaturgia skutočnosti}

Ďalšími tvorcami, ktorých je relevantné spomenút v štúdii venujúcej sa integrácii zdravotne znevýhodnených osôb prostredníctvom divadelného umenia, sú osobnosti pôsobiace v nemeckom zoskupení Rimini Protokoll a švajčiarsky režisér Milo Rau. Vo svojej tvorbe sa nevenujú špeciálne práci so znevýhodnenými, aj ked' niektoré ich realizácie takúto prax zahŕňajú. V kontexte našej štúdie je zaujímavé uvažovat nad divadlom z perspektívy ich metódy práce s nehercami, ktorá sa stáva modelom narábania a spolupráce s respondentom.

Protagonisti sú v takomto divadle samými sebou a na javisku súčasne interpretujú úlohu. Realita a fikcia sú tu vzájomne prepojené. Ide o podobný princíp práce s interpretom ako u súborov analyzovaných v predchádzajúcej podkapitole. Aj na základe tohto pozorovania by sme mohli povedat', že v divadelnej praxi ide o tendenciu, ktorá významne prispieva k výskumu, poznaniu a spoločenskej integrácii znevýhodneného človeka. Prepájanie foriem story tellingu, dokumentu, prednášok, inštalácií alebo až takmer terapií má u týchto súborov povahu experimentálneho priestoru, ktorý rozširuje a pretvára hranice chápania divadla v medzinárodnom kontexte.

Zoskupenie Rimini Protokoll, ktoré vzniklo v roku 2000 spoluprácou režisérky Helgard Haug a divadelných teoretikov Stefana Kaegiho a Daniela Wetzela, vo svojej praxi nepretržite rozširuje divadelné prostriedky a vytvára nové pohl'ady na realitu. Na začiatku nultých rokov 21. storočia sa v nemecky hovoriacom divadle objavil s príchodom Rimini Protokoll (a d’alších skupín, napr. Gob Squad, SheShePop, Auftrag: Lorey) nový termín súvisiaci s divadlom - „Expertentheater “52. Zoskupenia majú rôzne štýly a dramaturgiu, spája ich však skutočnost', že na javisku sa v ich predstaveniach objavujú respondenti. Nehrajú fiktívne úlohy v dramatickom texte, na javisku konajú sami za seba. Väčšina predstavení sa vytvára rozprávaním o ich vlastných skúsenostiach alebo životoch. Týkajú sa l’udí, ktorí majú špeciálnu skúsenost', alebo vynikajú vo svojom odbore, preto sa im hovorí "Alltagsspezialisten"53. Podstatnú zložku prípravy projektov tvorí diskusia s odborníkmi a dramaturgická práca so skúmaným materiálom. Takéto divadelné formy by mohli byt’ považova-

\footnotetext{
${ }^{51}$ Pozri BUGIEL, M. - ELBER, M. Theater Hora. Berlin : Theater der Zeit, 2014.

52 TERAO, E. Inszenierte Authentizität. Eine Aufführungsanalyse von "TESTAMENT" als Expertentheater. 2013. [online]. [cit. 10. 10. 2020]. Dostupné na internete: https://www.grin.com/document/412633.

${ }^{53}$ Tamže.
} 
né za kritického nástupcu Regietheater (režisérskeho divadla), ktoré v nemecky hovoriacom štátnom divadle prekvitalo od šestedesiatych rokov. V analyzovaných divadelných formách vidiet’ na jednej strane stále prítomné prostriedky režisérskeho divadla, ako sú ansámbel a metateatrálna perspektíva, na druhej strane je tu však dôležitá otázka významu herca, ktorý sa dlho považoval iba za sprítomnenie nástroja na sprostredkovanie textu pre divákov.

V diskusiách o smerovaní a cieloch súčasného divadla prináša radikálne nové myšlienky švajčiarsky režisér Milo Rau. Aj on vo svojich dielach pracuje s rôznorodými skupinami l'udí, nevynímajúc zdravotne znevýhodnené osoby. Sám spolupracuje napríklad s divadlom HORA. Po zásadných autorských projektoch, ktoré preformulovali spôsob vnímania javiskového diela, preniesol svoje vízie aj do smerovania v NTGent, kde v súčasnosti pôsobí ako umelecký riaditel. Myšlienky, ktoré pri svojom nástupe do funkcie (2018) sformuloval do desatbodového manifestu tejto inštitúcie, prinášajú zásadné otázky týkajúce sa budúcnosti divadla vo všeobecnosti. ${ }^{54} \mathrm{Aj}$ ked' manifest vychádza predovšetkým z Rauovej skúsenosti so systémom mestských divadiel $\mathrm{v}$ Nemecku, jeho obsah a myšlienky sú uplatnitelné i v širšom kontexte. ${ }^{55}$ Hlavnou otázkou je, ako bude "mestské divadlo budúcnosti“ vyzerat: kto v ňom bude účinkovat', ako bude prebiehat' skúšobný proces, vytvorenie produkcií a ich hostovania. Body manifestu, ktoré významným spôsobom súvisia aj s integráciou, hovoria o divadle, ktoré nie je obyčajným zobrazením sveta, ale má prispiet’ $\mathrm{k}$ jeho premene. Ciel’om nie je znázorňovat', ale vytvorit’ reprezentáciu, ktorá je sama osebe skutočnostou. Ďalej sa Rau zamýšl’a nad tým, že divadlo nie je produktom, ale výrobným procesom a výskumom, ktorý by mal byt๋ verejne prístupný. Dôležitou podmienkou pre nadchádzajúce sezóny v Gente bude obsadenie produkcií interpretmi, z ktorých vždy minimálne dvaja v každej inscenácii musia byt nedivadelníci. Divadlo $\mathrm{v}$ tomto koncepte nie je primárne o dekorácii: v ôsmom bode manifestu sa ako maximálny objem scénickej výpravy uvádza 20 metrov kubických, aby ju bolo možné transportovat' v štandardnom dopravnom prostriedku bez potreby špeciálneho vodičského preukazu. Zrejme najradikálnejším bodom je podmienka uvedenia alebo naštudovania minimálne jednej produkcie vo vojnovej alebo konfliktnej zóne bez kultúrnej infraštruktúry. Všetky body manifestu sú túžbou po slobodnom spôsobe divadelnej práce, neviazanej na konvenčné očakávania. Nie je ich ale jednoduché implementovat', pretože ku zmene paradigmy divadelného predstavenia, ktoré už nie je ani klasickou inscenáciou, ani režisérskym reinterpretačným divadlom, ale prakticky ide o novú formou performatívneho umenia, sa vztahuje rad politických a spoločenských rozhodnutí - od fungovania hercov, ktorí už netvoria ansámbel a ocitajú sa v pozícii slobodného povolania, až po otázku ekonomickej udržatel’nosti v súvislosti s prevádzkou inštitúcie.

\section{Záver}

Podl’a rôznych teoretických štúdií a divadelnej praxe, snahou estetiky zdravotného postihnutia nie je prijatie alebo odmietnutie samotného postihnutia, ale skôr jeho

\footnotetext{
${ }^{54}$ Pozri [Bez autora]. Manifest. [online]. [cit. 10. 11. 2020]. Dostupné na internete: https://www.ntgent. be/en/manifest.

${ }_{55}$ Pozri IRMER, T. The utopia of international theatre. In Theater der Zeit, 2019, roč. 74, č. 7/8, s. 28.
} 
ustanovenie $\mathrm{v}$ zmysle samostatnej estetickej hodnoty, ktorá vedie divadlo do modernej doby - ide teda o pokus chápat’ zdravotné postihnutie ako zdroj rozšíreného spektra emocionálnej reprezentácie.

Umožnit takýmto umelcom, aby sa stali súčastou bežnej kultúry, nie je len otázkou reprezentácie a sociálnej spravodlivosti. Umelci so zdravotným postihnutím prinášajú nové skúsenosti a formy, sú prínosom a rozširujú spektrum možností v umení a kultúre. Ich integrácia je výhodou nielen pre kultúrnych producentov, ale aj pre divákov. Bezbariérovú spoločnost’ nevytvára primárne umenie, to ale môže proces integrácie významne iniciovat’ a sprevádzat'.

Divadlo sa od svojich počiatkov vždy aktualizovalo a obnovovalo, počnúc gréckym amfiteátrom alebo náboženskou procesiou a končiac digitálnymi performanciami. Petra Kuppers tvrdí: „Zdravotné znevýhodnenie, náhla zmena, zranitel’nost, zvedavost' na inakost’ a živé obrazy boli a nad’alej sú súčastou divadelného príbehu. Divadlá sú domovom pre mnohých a mnohé z nás, sú to miesta, ktoré sa stávajú laboratóriami novej i starej kultúry, laboratória spôsobu, ako sa hl'adat' a nachádzat' v spoločnosti, i spôsobu, ako sa predvádzat' na verejnosti. Tvorit' divadlo o znevýhodnených a pre nich, ako aj spoločná práca na predstaveniach, to všetko je posilňujúce a premieňajúce. ${ }^{\prime 56}$

V súčasnej spoločnosti stále nie sú vytvorené podmienky na to, aby inklúzia prebiehala prirodzene. $V$ divadle prezentujúcom znevýhodneného človeka je publikum často nepokojné a musí si na zmenu zvykat'. Inklúzia v kontexte našej štúdie sa začína neistotou umelca a vedie $\mathrm{k}$ publiku, ktoré je tiež znepokojené. Je dôležité, aby sa o týchto projektoch diskutovalo a premýšlalo. Tak môže dôjst' k strednodobému úspechu, ktorý bude podporovaný vytváraním a posilňovaním sietí a l'udí, ktorí budú tieto myšlienky d’alej uskutočňovat'. V kultúrnej praxi ide o festivaly a organizácie venujúce sa sietovaniu podobných projektov. Profesionálna činnost herca so zdravotným postihnutím $\mathrm{v}$ profesionálne riadenom divadle predstavuje možnost’ sociálnej emancipácie. Divadlo so zdravotne postihnutými l'ud’mi nie je neznáme ani neobvyklé, ale skutočnost', že herci sú pozývaní na medzinárodné festivaly ako profesionáli a za svoju prácu dostávajú honoráre, možno považovat za pozitívny prípad inklúzie a emancipačný úspech. Dráma ponúka hercom možnost’ eliminovat’ bariéry ich zdravotných znevýhodnení. Sociálne normy i klišé hendikepu a dokonalosti sú tu podrobované irónii či vtipu a vážne spoločenské problémy sa často menia na absurdné.

Miera integrácie l’udí so znevýhodnením je zrkadlom systémových nastavení a politiky. Podla publikácie Súčasné slovenské divadlo v dobe spoločenských premien, ktorá sa popri inom venuje aj mapovaniu aktivít podobných divadelných zoskupení v slovenskom kontexte, sa v našom divadelníctve táto tvorba „,v posledných rokoch čiastočne profesionalizuje (...) a domáha sa práva vstúpitł do širšieho divadelného kontextu“ ${ }^{\prime 57}$. Situácia marginalizovaných skupín v kontexte slovenského divadla je tu hodnotená ako postavenie „na okraji hlavného prúdu slovenského činoherného divadla“58. Z toho vyplývajú zásadné obmedzenia, pre ktoré sa nedokážu vo väčšej

\footnotetext{
${ }^{56}$ KUPPERS, P. Divadlo a zdravotné znevýhodnenie, s. 42.

${ }^{57}$ LINDOVSKÁ, N. Divadlo v hl’adaní staro/nových identít. In KNOPOVÁ, E. (ed.). Súčasné slovenské divadlo $v$ dobe spoločenských premien. Bratislava : Veda, 2017, s. 248.

${ }^{58}$ Tamže.
} 
miere generovat divadelné produkcie a súbory s optimálnym zázemím, porovnatel'ným s vyššie spomenutými zahraničnými divadlami. Napriek tomu na Slovensku už dlhodobo funguje niekol'ko súborov a tvorcov, ktorí prispievajú do teatrologického diskurzu vysoko kvalitnými konceptmi.

\section{THEATRICAL ART AS A TOOL FOR THE INTEGRATION OF INDIVIDUALS WITH HEALTH IMPAIRMENTS: CONTRIBUTION OF THEATRE TO PEOPLE WITH AUTISTIC SPECTRUM DISORDER}

\section{Peter MAZALÁN}

The study in an analysis of the relationship between theatrical art and the mental health impairments associated with Autism Spectrum Disorder. Apart from using theatre for education and social and clinical practice, we have a look at progressive, international and professional theatre institutions, which contribute significantly to the discussion on neurodiversity. Despite the fact that modern medicine has an impact on the change to the social paradigm towards the acceptance of people with mental impairments, the level of stigmatisation within society is still quite high. The study examines, within theatre or by theatrical means, the forms of inclusion which contributes to a cultural diversity that is an extension of an open and tolerant society.

Výskum z verejných zdrojov podporil Fond na podporu umenia (projekt č. 20-361-04588, Performatíne umenie v kontexte l'udskej neurodiverzity).

\section{LITERATÚRA}

[Bez autora]. Aktuálne trendy nového medzinárodného etického kódexu. [online]. [cit. 11. 2. 2021]. Dostupné na internete: https://socialniprace.cz/aktualne-trendy-noveho-medzinarodneho-etickeho-kodexu/.

[Bez autora]. Relaxed Performance. [online]. [cit. 15. 10. 2020]. Dostupné na internete: https:// diversity-arts-culture.berlin/en/node/127.

[Bez autora]. Equality Acts 2010. Dostupné na internete: https://www.legislation.gov.uk/ukpga/2010/15/contents [online]. [cit. 15. 10. 2020].

[Bez autora]. Manifest. [online]. [cit. 10. 11. 2020]. Dostupné na internete: https://www.ntgent. be/en/manifest.

[Bez autora]. Relaxed Performances, 16. 3. 2016. [online]. [cit. 25. 8. 2020]. Dostupné na internete: https://www.touretteshero.com/2016/03/16/relaxed-performances-the-faqs/.

[Bez autora]. Theater Rambazamba. [online]. [cit. 1. 11. 2020]. Dostupné na internete: https://web. archive.org/web/20070403132354/http://www.theater-rambazamba.org/Aboutus/selbstdarst.

[Bez autora]. Theater Thikwa. [online]. [cit. 1. 11. 2020]. Dostupné na internete: https://www. thikwa.de/ueber-thikwa/ueber-thikwa-profil/.

[Bez autora]. The European Mental Health Action Plan 2013-2020, September 2013. [online]. [cit. 1. 12. 2020]. Dostupné na internete: http://www.euro.who.int/_data/assets/pdf_ file/0020/280604/WHO-Europe-Mental-Health-Acion-Plan-2013-2020.pdf.

BOLDT, Joachim. The Concept of Vulnerability in Medical Ethics and Philosophy. In Philos 
Ethics Humanit Med, 2019, roč. 14, č. 6. [online]. [cit. 11. 2. 2021]. Dostupné na internete: https://doi.org/10.1186/s13010-019-0075-6.

BUGIEL, Marcel - ELBER, Michael. Theater Hora. Berlin : Theater der Zeit, 2014. 672 s. ISBN 978-3-943881-76-9.

CONROY, Colette. Divadlo a telesnost'. Bratislava : Divadelný ústav, 2017. 112 s. ISBN 978-808190-029-7.

DEDERICH, Markus. Körper, Kultur und Behinderung. Eine Einführund in die Disability Studies. Bielefeld : Transcipt, 2007. 208 s. ISBN 978-3-8394-0641-0.

DREYSSE, Miriam - MALZACHER, Florian. Experten des Alltags. Das Theater von Rimini Protokoll. Berlin : Alexander Verlag, 2007. 232 s. ISBN 978-3-89581-181-4.

DUBAČOVÁ, Viera. Terapia divadlom. Nitra : Univerzita Konštantína Filozofa, 2013. 98 s. ISBN 978-80-558-0394-4.

FLETCHER - WATSON, Ben. Relaxed performance: audiences with autism in mainstream theatre. In The Scottish Journal of Performance, 2015, roč. 2, č. 2, s. 61 - 89. [online]. [cit. 10. 10. 2020]. ISSN 2054-1961. Dostupné na internete: https://www.scottishjournalofperformance. org/Fletcher-Watson_relaxed-performance_SJoP0202_DOI_10.14439sjop.2015.0202.04.html.

FREUD, Sigmund. Psychopatische Personen auf der Bühne. In MITSCHERLICH, Alexander et al. Freud - Studienausgabe. Frankfurt am Main : Fischer, 1969. 258 s. ISBN 9783108227029.

FREUD, Sigmund. The Ego and the Id. In TACD Journal, 1989, roč. 17, č. 1, s. p. 5 - 22. ISSN 15566382.

FRITH, Uta. Autism: explaining the enigma. Oxford : Blackwell Publishing, 1989. ISBN 0-63122901-9.

GODFREY, Emma - HAYTHORNE, Deborah. Benefits of dramatherapy for Autism Spectrum Disorder. In Dramatherapy, 2013, roč. 35, č. 1, s. 20 - 28. [online]. [cit. 20. 11. 2020]. Dostupné na internete: https://www.tandfonline.com/toc/rdrt20/35/1?nav=tocList ISSN 2157-1430.

GOFFMAN, Erving. Všichni hrajeme divadlo. Praha : Nakladatelství Studia Ypsilon, 1999. 248 s. ISBN 80-902482-4-1.

GOTTWALD, Claudia. Lachen über das andere. Eine historische Analyse komischer Repräsentationen von Behinderung. Bielefeld : Transcript, 2009. 330 s. ISBN 978-3-8376-1275-2.

HRONSKÝ, Michal. Vnímanie vnútorného priestoru, kompozičné princípy. In DANIEL, P. et al. Interiérový dizajn. Bratislava : Spektrum, 2017. 326 s. ISBN 978-80-227-4750-9.

IRMER, Thomas. The utopia of international theatre. In Theater der Zeit, 2019, roč. 74, č. 7/8, s. 28 - 35. ISBN 978-3-95749-190-9.

JAARSMA, Pier - WELIN, Stellan. Autism as a Natural Human Variation: Reflections on the Claims of the Neurodiversity Movement, 11. 2. 2011. [online]. [cit. 1. 12. 2020]. Dostupné na internete: https://link.springer.com/article/10.1007/s10728-011-0169-9.

KASIRER, Anat. - MASHAL, Nira. Comprehension and generation of metaphors by children with autism spectrum disorder. In Research in Autism Spectrum Disorders, 2016, roč. 32, december, s. 53 - 63. [online]. [cit. 20. 9. 2020]. ISSN 1750-9467. Dostupné na internete: https:// psycnet.apa.org/record/2016-54476-006.

KNOPOVÁ, Elena. Na ceste od terapie umením ku komunitnému divadlu. In BALLAY, Miroslav et al. Divadlo nielen ako umelecká aktivita. [online]. [cit. 8. 2. 2021]. Bratislava : SAV, 2014. 62 s. ISBN 978-80-971155-2-4. Dostupné na internete: http://www.udfv.sav.sk/dokumenty/ Divadlo.nielen.ako.umelecka.aktivita.pdf.

LINDOVSKÁ, Nadežda. Divadlo v hladaní staro/nových dentít. In KNOPOVÁ, Elena (ed.). Súčasné slovenské divadlo $v$ dobe spoločenských premien. Bratislava : Veda, 2017. 368 s. ISBN 978-80-224-1620-7

KUPPERS, Petra. Divadlo a zdravotné znevýhodnenie. Bratislava : Divadelný ústav, 2019. $112 \mathrm{~s}$. ISBN 978-80-8190-049-5.

LINZER, Martin. Inklusion - was'n ditte? In Theater der Zeit, 2014, roč. 68, č. 4, s. 16 - 17. ISSN-Nr. 0040-5418. 
NAGYOVÁ, Nora. K základným atribútom výtvarnej poetiky Petra Čaneckého so zameraním sa na inscenácie v réžii Romana Poláka. In Slovenské divadlo, 2020, roč. 68, č. 1, s. 47-60. ISSN 0037-699X. DOI: https://doi.org/10.31577/sd-2020-0004.

PEARSON, Jenny. Marian "Billy“ Lindkvist obituary, 15. 3. 2017. [online]. [cit. 20. 11. 2020]. Dostupné na internete: https://www.theguardian.com/society/2017/mar/15/marian-billy-lindkvist-obituary.

ROSELT, Jens. Der Zuschauer als Täter. In Ästhetik versus Authentizität? Reflexionen über die Darstellung von und mit Behinderung. (Ed. Imanuel Schipper). Berlin : Theater der Zeit, 2012, s. 81 - 91. ISBN 978-3-942449-42-7.

SANDAHL, Carrie. Ahhhh Frea Out! Metaphors of Disability and Femaleness in Performance. In Theatre topics, 1999, roč. 9, č. 1, s. 11 - 30. ISSN 1054-8378.

SCHEUGL, Hans. Show - Freaks und Monster. Sammlung Felix Adanos. Köln : DuMont Schauberg, 1978. 186 s. ISBN 9783770107339.

SCHIPPER, Imanuel. Einleitung. In Ästhetik versus Authentizität? Reflexionen über die Darstellung von und mit Behinderung. (Ed. Imanuel Schipper). Berlin : Theater der Zeit, 2012, s. 7 - 11. ISBN 978-3-942449-42-7.

SCHMIDT, Yvonne. Perform to be a Freak. In Ästhetik versus Authentizität? Reflexionen über die Darstellung von und mit Behinderung. (Ed. Imanuel Schipper). Berlin : Theater der Zeit, 2012, s. 118 - 129. ISBN 978-3-942449-42-7.

SIEBERS, Tobin. Un/Sichtbar. Observationen über Behinderung auf der Bühne. In Ästhetik versus Authentizität? Reflexionen über die Darstellung von und mit Behinderung. (Ed. Imanuel Schipper). Berlin : Theater der Zeit, 2012, s. 16 - 32. ISBN 978-3-942449-42-7.

TERAO, Ehito. Inszenierte Authentizität. Eine Aufführungsanalyse von "TESTAMENT" als Expertentheater. 2013. [online]. [cit. 10. 10. 2020]. Dostupné na internete: https://www.grin.com/ document/412633.

TIGGES, Steffan - PEWNY, Katharina - DEUTSCH-SCHREINER, Evelyn et al. Zwischenspiele - Neue Texte, Wahrnehmungs und Fiktionsräume in Theater, Tanz und Performance. Bielefeld: Transcript Verlag, 2010. 474 s. ISBN 978-3-8376-1015-4

VALENTA, Milan. Dramatoterapia. Praha : Portál, 2000. 152 s. ISBN 80-7178-586-5.

Peter Mazalán

Fakulta architektúry a dizajnu

Slovenská technická univerzita

Námestie slobody 2911/19

81245 Bratislava

e-mail: peter.mazalan@gmail.com 